\title{
Randomized By Mistake
}

National Cancer Institute

\section{Source}

National Cancer Institute. Randomized By Mistake. NCI Thesaurus. Code C139237.

An indication that the subject was randomized but should not have been. 